\title{
Larvicidal activity of Ocimum campechianum, Ocotea quixos and Piper aduncum essential oils against Aedes aegypti
}

Laura Scalvenzi $^{1}$, Matteo Radice ${ }^{1}$, Luciano Toma ${ }^{3}$, Francesco Severini ${ }^{3}$, Daniela Boccolini ${ }^{3}$, Antonino Bella ${ }^{3}$, Alessandra Guerrini ${ }^{2}$, Massimo Tacchini ${ }^{2}$, Gianni Sacchetti ${ }^{2}$, Matteo Chiurato ${ }^{2}$, Roberto Romi ${ }^{3}$, and Marco Di Luca ${ }^{3, *}$

${ }^{1}$ Department of Earth Sciences, Universidad Estatal Amazónica, Km 21ํㄹ Via Puyo-Tena, 160150 Puyo, Ecuador

${ }^{2}$ Department of Life Sciences and Biotechnology (SVeB), University of Ferrara, P.le Chiappini, 3, Malborghetto di Boara, 44123 Ferrara, Italy

${ }^{3}$ Department of Infectious Diseases, National Institute of Health (Istituto Superiore di Sanità, ISS), V.le Regina Elena 299, 00161 Rome, Italy

Received 28 October 2018, Accepted 2 April 2019, Published online 17 April 2019

\begin{abstract}
Aedes aegypti, the main arbovirus vector of the Yellow fever, Dengue, Chikungunya and Zika viruses, is widely distributed in tropical and subtropical areas throughout the world. Preventive control efforts have been implemented worldwide aimed at reducing its impact on human health. The recent reduction of chemicals available for vector control due to their negative impact on the environment and human health and the increase in mosquito resistance to insecticides have driven the research community to identify and evaluate sustainable alternatives to synthetic insecticides. In this study, the potential larvicidal effect of essential oils extracted from Ocimum campechianum, Ocotea quixos and Piper aduncum were tested in vitro. GC and GC-MS analyses showed that the main compounds were eugenol (18\%), 1,8-cineole (39\%) and dillapiole (48\%), respectively. Susceptibility to essential oils was measured according to the WHO protocol. After $24 \mathrm{~h}$, the mean percentage mortality ranged from 2.7 to $100 \%$ for P. aduncum, from 2.2 to $100 \%$ for $O$. campechianum, and from 2.9 to $100 \%$ for $O$. quixos. The highest potential was displayed by $P$. aduncum, followed by $O$. campechianum and $O$. quixos, with $\mathrm{LC}_{50}$ values of $25.7,69.3$ and $75.5 \mathrm{ppm}$, respectively. The rapid and effective larvicidal activity of these three oils led us to consider these results to be promising, also considering the possibility of local cultivation of these plants in tropical and subtropical areas and the simple technology for their large-scale preparation and production. Further studies are needed to evaluate the individual components and their activity as larvicides.
\end{abstract}

Key words: Ocimum campechianum, Ocotea quixos, Piper aduncum, Essential oil, Larvicidal activity, Aedes aegypti.

Résumé - Activité larvicide des huiles essentielles d'Ocimum campechianum, Ocotea quixos et Piper aduncum contre Aedes aegypti. Aedes aegypti, le principal vecteur d'arbovirus qui provoque la Fièvre Jaune, la Dengue, le Chikungunya et le Zika, est largement répandu dans les régions tropicales et subtropicales du monde entier. Des efforts de contrôle préventif ont été mis en œuvre dans plusieurs pays afin de réduire son impact sur la santé humaine. La récente réduction des produits chimiques disponibles pour la lutte antivectorielle, en raison de leur impact négatif sur l'environnement et la santé humaine, et l'augmentation de la résistance des moustiques aux insecticides, ont amené la communauté des chercheurs à identifier et évaluer des alternatives durables aux insecticides synthétiques. Dans cette étude, l'effet larvicide potentiel des huiles essentielles extraites de Ocimum campechianum, Ocotea quixos et de Piper aduncum a été testé in vitro. Les analyses GC et GC-MS ont montré que les principaux composés étaient respectivement l'eugénol (18\%), le 1,8-cinéole (39\%) et le dillapiole (48\%). La sensibilité aux huiles essentielles a été mesurée conformément au protocole de l'OMS. Après 24 heures, le pourcentage moyen de mortalité variait de 2.7 à $100 \%$ pour $P$. aduncum, de 2.2 à $100 \%$ pour $O$. campechianum et de 2.9 à $100 \%$ pour $O$. quixos. $P$. aduncum a affiché le potentiel le plus élevé, suivi de $O$. campechianum et de O. quixos, avec des valeurs $\mathrm{CL}_{50}$ de respectivement $25.7,69.3$ et $75.5 \mathrm{ppm}$. L'activité larvicide rapide et efficace de ces trois huiles nous a amenés à considérer les résultats comme prometteurs, compte tenu également de la possibilité de culture locale dans les zones tropicales et subtropicales de ces plantes et de la technologie simple pour leur préparation et leur production à grande échelle. Des études complémentaires sont nécessaires pour évaluer les composants individuels et leur activité en tant que larvicides.

*Corresponding author: marco.diluca@iss.it

This is an Open Access article distributed under the terms of the Creative Commons Attribution License (http://creativecommons.org/licenses/by/4.0), which permits unrestricted use, distribution, and reproduction in any medium, provided the original work is properly cited. 


\section{Introduction}

Aedes aegypti, also named "yellow fever mosquito", is native to Africa and now widely spread in tropical and subtropical areas throughout the world. The mosquito reached the New World from Africa by means of slave ships; casks used for shipboard storage of water must have been breeding sites for the mosquito [14]. Ae. aegypti is known for its relevant worldwide role as the main vector of the yellow fever virus (YFV), for which a vaccine exists, and of dengue virus (DENV), Zika virus (ZIKV), chikungunya virus (CHIKV), and other arboviruses, for which no vaccine is currently available. In particular, YFV remains a dramatic public health problem in the subtropical areas of South America and West Africa [49]. Recently, ZIKV, responsible for microcephaly, congenital nervous system malformations and Guillain-Barré syndrome has circulated in some areas of South-East Asia, tropical Africa and South America where outbreaks of infection have been well documented [50]. To take action against this mosquito vector, also able to transmit additional arboviruses heavily affecting humans, preventive control efforts are implemented worldwide and aim to reduce the impact of this mosquito species on human health.

Concerning arboviral diseases, the risk of transmission is strongly linked to vector density and for this reason, density should be rapidly reduced by vector control activities. In general, the use of synthetic insecticides has been the basis of vector control in limiting mosquito-borne diseases such as malaria, chikungunya (CHIK), dengue (DENV) and West Nile (WNV). However, over the past ten years, pesticide registration procedures aimed at minimising the negative impact of pesticides on the environment and on human health, and the widespread evolution of insecticide resistance in mosquito populations [11], have reduced the number of chemicals available for vector control [48]. As a consequence, worldwide research efforts to discover sustainable alternatives to synthetic insecticides have been implemented around plant-based pesticides that are as selective as possible toward mosquitoes [35].

Herbal extracts, linked to traditional knowledge and folk medicine, represent an almost unlimited source of bioactive compounds widely used as treatments for various human diseases [3, 7, 24] but also a source of insecticides and insect repellents. The use of plant extracts for insect control has a long historical tradition dating back 3000 years, when extracts from aromatic plants were used as repellents against ectoparasites and anthelmintics, as well as to preserve harvested foods from pests. In the 20th century, studies related to the pesticide effects of essential oils gained momentum [29]. These plant metabolites may be less sensitive to resistance development in insect populations because they are complex mixtures of numerous bioactive compounds that likely differ in their modes of action [4]. Essential oils obtained from basil (Ocimum spp.) have been found to be effective in repelling some species of beetles infesting foodstuffs [26]; other extracts from cumin (Cuminum cyminum), anise (Pimpinella anisum) and origan (Origanum syriacum var. bevanii) are effective against aphids and other phytophagous pests [46]. These compounds are widely used for the control of insects of health interest, such as mosquitoes.
In an effort to identify new larvicidal active ingredients (AIs) effective against Ae. aegypti, the potential larvicidal effects of essential oils extracted from Ocimum campechianum Mill. (syn. Ocimum micranthum Willd.), Ocotea quixos (Lam.) Kosterm. and Piper aduncum L., were tested in vitro in this study. O. campechianum is a plant species in the Lamiaceae family, widespread across Central and South America. Previous studies on essential oils from Ocimum species showed promising results on the larvae of Ae. aegypti [9] and also against other insect species [18]. $O$. quixos is an evergreen tree in the Lauraceae family, native to Ecuador and Colombia. Species from the same genus, such as $O$. cymbarum, showed a remarkable mortality effect on Ae. aegypti larvae [40]. P. aduncum is an evergreen, shade-tolerant, shrubby tree in the Piperaceae family, native to the West Indies and tropical America. Essential oils from the Piper genus are recognised as having insecticidal effects against a large number of insects. In particular, $P$. aduncum essential oil recorded very good activity against the Ae. aegypti mosquito [25].

These three plant species were selected because they belong to genera with promising chemical characteristics when used as insecticides, and because they are from Ecuador, which belongs to a selected group of 17 countries defined as "Megadiverse" due to their impressive biological diversity [21, 43], an important source of possible bioactive compounds. Essential oils from the Ecuadorian Amazon Region have been investigated in the last few decades in order to deepen our understanding of their biological activities [9, 19, 38, 39, 45]. To our knowledge, studies evaluating the larvicidal effects of essential oils from Ecuadorian plants against Ae. aegypti have not been reported to date.

\section{Materials and methods}

\section{Plant material and extraction of essential oils}

Aerial parts of $O$. campechianum, $O$. quixos and $P$. aduncum were collected from a wild population in the Amazonian region of Pastaza (Ecuador). Species authentication was certified by Dr. David Neill and voucher specimens from each plant were deposited at the Herbarium ECUAMZ of the Amazonian State University (UEA) in Ecuador (voucher specimen: Radice 18070D, Neill 18070B, Scalvenzi 18070C).

The essential oils were obtained by hydrodistillation in a stainless steel distiller equipped with a Clevenger apparatus. All essential oils were obtained performing three distinct distillations and essential oil (moisture-free) yield was $0.68 \%$ for O. micranthum, $0.13 \%$ for $O$. quixos, and $0.12 \%$ for $P$. aduncum, respectively. The oil was dried over anhydrous sodium sulphate and stored in sealed amber vials at $4{ }^{\circ} \mathrm{C}$.

\section{GC and GC/MS analyses}

Compound identification was carried out by gas chromatography and gas chromatography - mass spectrometry (GC and GC-MS) analyses, and the relative peak areas for individual compounds were averaged. For the analysis, a ThermoQuest GC-Trace gas chromatograph equipped with a FID detector 
and a Varian FactorFour VF-5 ms poly-5\% phenyl95\%-dimethylsiloxane column $(30 \mathrm{~m} \times 0.25 \mathrm{~mm}$ i.d., film thickness: $0.15 \mu \mathrm{m}$ ) were used. Operating conditions were as follows: injector temperature $250{ }^{\circ} \mathrm{C}$, FID temperature $250{ }^{\circ} \mathrm{C}$, carrier (Helium) flow rate $1 \mathrm{~mL} / \mathrm{min}$, and split ratio $1 / 20$. The initial oven temperature was $55{ }^{\circ} \mathrm{C}$ and then increased to $100{ }^{\circ} \mathrm{C}$ at a rate of $1{ }^{\circ} \mathrm{C} / \mathrm{min}$, then to $250{ }^{\circ} \mathrm{C}$ at a rate of $5{ }^{\circ} \mathrm{C} / \mathrm{min}$ and then kept constant at $250{ }^{\circ} \mathrm{C}$ for $15 \mathrm{~min}$. One microliter for each replicate was dissolved in $\mathrm{CH}_{2} \mathrm{Cl}_{2}$ and injected. The oil percentage composition was computed by the normalisation method from the GC peak areas, without using correction factors. The chemical characterisation of essential oil compounds was performed by a Varian GC-3800 gas chromatograph equipped with a Varian MS-4000 mass spectrometer using electron impact and hooked to NIST 05 (National Institute of Standards and Technology) Mass Spectral Library. The conditions were the same as those described for GC analysis and the same column was also used. The mass spectroscopy conditions were as follows: ionisation voltage, $70 \mathrm{eV}$; emission current, $10 \mu \mathrm{Amp}$; scan rate, $1 \mathrm{scan} / \mathrm{s}$; mass range, 29-400 Da; trap temperature, $150{ }^{\circ} \mathrm{C}$, transfer line temperature, $300{ }^{\circ} \mathrm{C}$. The essential oil compounds were characterised by comparing their relative retention times, KI, and the MS fragmentation pattern with those of other known essential oils, with pure compounds and by matching the MS fragmentation patterns and retention indices with the above-mentioned mass spectra libraries and with those in the literature [2]. The Kovats index of the components was determined adding a $\mathrm{C}_{8}-\mathrm{C}_{32} n$-alkanes (Sigma-Aldrich) to the essential oil before injecting in the GC-MS equipment and analysed under the same conditions reported above [19].

The local name and main essential oil compounds are shown in Table 1. For the larvicidal assays, the essential oil was dissolved in a solution of $1 \%$ dimethyl sulfoxide (DMSO) in test medium.

\section{Larvicidal assay}

A long-established laboratory colony of Ae. aegypti (collected in Reynosa, Mexico, in 1998) was used as a susceptible strain for larvicidal bioassays. To allow hatching, eggs were placed in plastic trays $(30 \times 15 \times 10 \mathrm{~cm})$ containing $1 \mathrm{~L}$ of dechlorinated tap water. The larvae were reared in a climatic chamber at a temperature of $27 \pm 1{ }^{\circ} \mathrm{C}, 80 \pm 10 \%$ relative humidity, and a photoperiod of 14:10 h light:dark, until reaching adulthood. The bioassays were performed according to the procedure of the World Health Organization [47]. Specifically, every bioassay was carried out in a climatic chamber with the above-reported temperature and photoperiod and replicated three times with mosquitoes from different rearing batches.

Each essential oil was dissolved in dimethylsulphoxide (DMSO) to prepare graded concentrations of tested material. Tests consisted of at least three replicates per concentration and were performed by serial dilutions of each oil (1000, $500,250,100,75,50,37.5,25$, and $12.5 \mu \mathrm{g} / \mathrm{mL}$ ). Batches of 25 late $3 \mathrm{rd} /$ early 4 th-stage larvae were exposed to different doses of each oil in plastic cups, each containing $250 \mathrm{~mL}$ of
Table 1. Chemical characterisation of essential oil from leaves of Ocimum campechianum.

\begin{tabular}{|c|c|c|c|c|}
\hline No. & Component $^{\mathrm{a}}$ & Area $\%{ }^{b}$ & RI $\exp ^{c}$ & RI lit \\
\hline 1 & $\alpha$-pinene & 0.7 & 929 & 932 \\
\hline 2 & camphene & 0.1 & 944 & 946 \\
\hline 3 & sabinene & 0.3 & 967 & 969 \\
\hline 4 & $\beta$-pinene & 1.2 & 973 & 974 \\
\hline 5 & myrcene & 0.3 & 987 & 988 \\
\hline 6 & p-cymene & 0.5 & 1021 & 1020 \\
\hline 7 & o-cymene & 0.4 & 1025 & 1023 \\
\hline 8 & 1,8-cineole & 11.4 & 1028 & 1026 \\
\hline 9 & cis-ocimene & 8.0 & 1032 & 1032 \\
\hline 10 & linalool & 2.9 & 1101 & 1095 \\
\hline 11 & allo-ocimene & 0.1 & 1126 & 1128 \\
\hline 12 & $\alpha$-terpineol & 0.4 & 1193 & 1186 \\
\hline 13 & $\delta$-elemene & 0.6 & 1337 & 1335 \\
\hline 14 & eugenol & 18.6 & 1363 & 1356 \\
\hline 15 & $\alpha$-copaene & 0.5 & 1376 & 1374 \\
\hline 16 & elemene isomer & 0.4 & 1383 & - \\
\hline 17 & $\beta$-elemene & 8.9 & 1388 & 1389 \\
\hline 18 & $\beta$-caryophyllene & 17.0 & 1410 & 1416 \\
\hline 19 & $\gamma$-elemene & 0.5 & 1427 & 1434 \\
\hline 20 & trans- $\alpha$-bergamotene & 0.4 & 1431 & 1435 \\
\hline 21 & $\alpha$-caryophyllene & 4.5 & 1451 & 1452 \\
\hline 22 & allo-aromadendrene & 1.5 & 1455 & 1458 \\
\hline 23 & germacrene D & 0.4 & 1477 & 1484 \\
\hline 24 & $\beta$-selinene & 1.8 & 1484 & 1489 \\
\hline 25 & viridiflorene & 0.2 & 1489 & 1696 \\
\hline 26 & bicyclogermacrene & 9.0 & 1490 & 1500 \\
\hline 27 & germacrene $\mathrm{A}$ & 1.4 & 1500 & 1508 \\
\hline 28 & germacrene B & 1.4 & 1556 & 1559 \\
\hline 29 & spathulenol & 1.9 & 1576 & 1577 \\
\hline \multirow[t]{2}{*}{30} & caryophyllene oxide & 1.7 & 1581 & 1582 \\
\hline & Total identified & 97.2 & & \\
\hline
\end{tabular}

${ }^{\text {a }}$ Components are listed in order of elution and their nomenclature is in accordance with the NIST 05 (National Institute of Standards and Technology) Mass Spectral Library.

${ }^{\mathrm{b}}$ Relative peak areas, calculated by GC-FID.

${ }^{\mathrm{c}} \mathrm{RI}$ exp: linear retention indices calculated on a VF-5 MS column.

${ }^{\mathrm{d}}$ RI lit: linear retention indices [2].

dechlorinated water. Over 8000 larvae were tested (a mean of 2700 per oil). After $24 \mathrm{~h}$ of exposure, during which no food was given to the larvae, mortality was checked (considering both dead and moribund larvae), and expressed as percentage mortalities. Larvae were considered moribund or dead when they showed unnatural positions, tremors, in coordination, or rigor; they did not respond to stimuli such as probing with a needle; or they were incapable of rising to the surface of the water.

Negative and positive control tests were performed in parallel for comparison. The first negative control contained ordinary laboratory larval rearing water; the second negative control contained an aqueous solution of $0.88 \%$ of dimethylsulfoxide (DMSO), used as a dispersing medium for the essential oils. The positive control contained an aqueous solution $0.05 \mathrm{mg} / \mathrm{L}$ of the organothiophosphate insecticide Fenthion (according to the diagnostic dosages for control of Ae. aegypti, indicated by the World Health Organization [47]. 
Table 2. Larvicidal effect of Piper aduncum, Ocimum campechianum and Ocotea quixos essential oils on Aedes aegypti at different concentrations, after $24 \mathrm{~h}$ of exposure, expressed as percentage of mortality.

\begin{tabular}{|c|c|c|c|c|c|c|c|c|c|c|c|c|c|c|c|}
\hline \multirow[t]{2}{*}{$\overline{\mathrm{EO}^{\mathrm{a}}}$} & \multirow{2}{*}{$\begin{array}{l}\text { Time } \\
\text { (h) }\end{array}$} & \multicolumn{8}{|c|}{ Concentration } & \multirow{2}{*}{$\begin{array}{l}\mathrm{LC}_{50}{ }^{\mathrm{b}} \\
\left(\mathrm{CI}_{95}\right)^{\mathrm{c}}\end{array}$} & \multirow{2}{*}{$\begin{array}{l}\mathrm{LC}_{90}{ }^{\mathrm{b}} \\
\left(\mathrm{CI}_{95}\right)^{\mathrm{c}}\end{array}$} & \multirow{2}{*}{$\begin{array}{c}\mathrm{LC}_{99}{ }^{\mathrm{b}} \\
\left(\mathrm{CI}_{95}\right)^{\mathrm{c}}\end{array}$} & \multirow{2}{*}{\multicolumn{2}{|c|}{$\mathrm{DF}^{\mathrm{d}} \mathrm{SLOPE}^{\mathrm{e}}$}} & \multirow[t]{2}{*}{$v^{2}$} \\
\hline & & 1000 & 500250 & 100 & 75 & 50 & 37.5 & 25 & 12.5 & & & & & & \\
\hline P. aduncum & 24 & 100 & 100100 & 100 & 100 & 100 & 95.7 & 42.6 & 2.7 & $\begin{array}{c}23.73 \\
(19.62-28.69)\end{array}$ & $\begin{array}{c}35.51 \\
(29.36-42.93)\end{array}$ & $\begin{array}{c}49.31 \\
(40.78-59.63)\end{array}$ & 2 & 7.43 & 0.003 \\
\hline O. campechianum & 24 & 100 & 100100 & 84.1 & 53.7 & 28.3 & 2.2 & 0 & 0 & $\begin{array}{c}69.29 \\
(58.69-81.81)\end{array}$ & $\begin{array}{c}109.46 \\
(92.71-129.24)\end{array}$ & $\begin{array}{c}158.91 \\
(134.59-187.63)\end{array}$ & 2 & 1.47 & 0.000 \\
\hline O. quixos & 24 & 100 & 100100 & 73.2 & 57.1 & 13.2 & 2.9 & 0 & 0 & $\begin{array}{c}75.51 \\
(63.22-90.19)\end{array}$ & $\begin{array}{c}122.56 \\
(102.6-146.39)\end{array}$ & $\begin{array}{c}181.89 \\
(152.28-217.26)\end{array}$ & 2 & 6.10 & 0.188 \\
\hline
\end{tabular}

${ }^{\mathrm{a}}$ EO: essential oil.

${ }^{\mathrm{b}}$ LC: lethal concentrations.

${ }^{\mathrm{c}} \mathrm{CI}$ : confidence intervals.

${ }^{\mathrm{d}}$ DF: dialysable fraction.

${ }^{\mathrm{e}}$ SLOPE: slope of regression line, $p$-value, $95 \%$.

\section{Statistical analysis}

A log-probit regression model for the three oils was obtained and toxicity was reported as lethal concentrations $\mathrm{LC}_{50}$ and $\mathrm{LC}_{90}$, representing the concentration in ppm necessary to cause $50 \%$ and $90 \%$ larval mortality, respectively, in $24 \mathrm{~h}$. The larvicidal mortality was corrected by Abbott's formula [1] and an $\mathrm{LC}_{50}, \mathrm{LC}_{90}$ regression equation, and the 95\% confidence limit was calculated by using probit analysis [17]. Probit analysis was performed by using the software by Dr. Alpha Raj. M "Free $\mathrm{LD}_{50} / \mathrm{LC}_{50}$ Calculator (2018 web version)" based on the Probit Analysis method of Finney [16].

\section{Results}

\section{Chemical characterisation of essential oils}

The compounds of $O$. campechianum essential oil are reported in Table 1; distillation yields were of $0.68 \%$. As previously published by us [34], the yields for $O$. quixos essential oil were $0.13 \%$, for $P$. aduncum $0.12 \%$. The essential oil of O. campechianum was found to be rich in eugenol $(18.6 \%)$, $\beta$-caryophyllene (17.0\%), 1,8-cineole (11.4\%), bicyclogermacrene (9\%), cis-ocimene (8\%) and $\alpha$-caryophyllene (4.5\%), that of $O$. quixos was characterised by 1,8-cineole (39.2\%), sabinene $(6.5 \%), \alpha$-pinene $(6.3 \%), \beta$-caryophyllene $(4.7 \%)$ and terpinen-4-ol (4.2\%), and P. aduncum essential oil showed a high percentage of dillapiole $(48.2 \%)$ followed by transocimene (7.5\%) and $\beta$-caryophyllene (4.8\%) [34].

\section{Larvicidal bioassay}

From the range of doses used, mortality was found to be dose-dependent. After $24 \mathrm{~h}$, the mean percentage mortality franged from 2.7 to $100 \%$ for P. aduncum, from 2.2 to $100 \%$ for O. campechianum, and from 2.9 to $100 \%$ for $O$. quixos. The interval observations in each concentration among oils showed the highest activity responses after $24 \mathrm{~h}$. The highest potential was displayed by $P$. aduncum, followed by $O$. micranthum and $O$. quixos, with an $\mathrm{LC}_{50}$ of $25.73,69.29$ and $75.51 \mathrm{ppm}$, respectively (Table 2, Fig. 1).

\section{Statistical analysis}

Regression models were determined from a minimum of three to a maximum of four points, giving a rate of mortality comprised between 2.2 and $95.7 \%$. All of the tests reported in this study provided regression lines with values of $\chi^{2}<5$, degree of freedom $>1$, and slope (from 0.54 to 0.8 ).

\section{Discussion and conclusion Essential oils}

The essential oil of O. campechianum was found to be rich mainly in eugenol (18.6\%) and $\beta$-caryophyllene (17.0\%), which is consistent with results reported by other authors $[22,38]$. The constituents of the essential oil obtained from $O$. quixos showed 1,8-cineole as the most abundant compound (39.2\%), confirming previous studies carried out in Ecuador [24]. Sabinene (6.5\%) and $\alpha$-pinene $(6.3 \%)$ were also found to be relevant compounds in other research [36, 41]. Nevertheless, the most characteristic compounds such as trans-cinnamaldehyde and $\beta$-caryophyllene were not found in the essential oil investigated in the present research. It is known that essential oils from the Ocotea genus usually show an high degree of chemodiversity, as reported in previous studies [33, 39], and this could explain its unusually composition. The essential oil of $P$. aduncum was mainly characterised by dillapiole $(48.2 \%)$, trans-ocimene $(7.5 \%)$ and $\beta$-caryophyllene $(17.0 \%)$, which is in line with other studies carried out on Ecuadorian Piper species [18].

Concerning the essential oil (EO) yields, it is important to point out that even though the distillation yields were low, the implementation of such EOs is feasible, due to the easy reproduction of the studied species, both on a spontaneous and human-mediated basis. Moreover, at least in the case of $O$. campechianum, studies on elicitation techniques have been reported for similar species $(O$. basilicum L.), showing promising results concerning the significant increase in total essential oil amount, using methyl salicylate, methyl jasmonate and chitosan as elicitors [15]. 

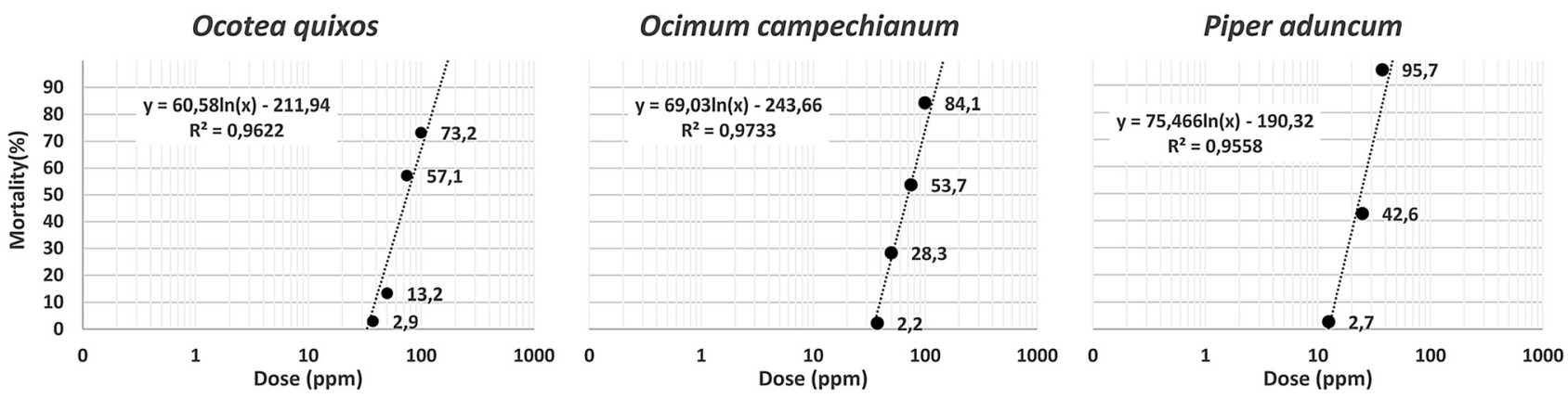

Figure 1. Log-probit regression lines from the analysis of the collected data about mortality rates in Ae. aegypti, for each tested essential oil.

\section{Anti-larval effects of essential oils}

The present study shows findings of Ae. aegypti larvicidal activity of three essential oils extracted from the leaves of $P$. aduncum, $O$. campechianum, and $O$. quixos from Ecuador. These encouraging results should stimulate the search for additional selective, eco-friendly larvicidal compounds from Ecuador, where the flora exhibits a richness in diversity of aromatic plants with potential as natural extracts for control of mosquito vectors.

Previous studies on Piper spp. have recognised that essential oils from plants belonging to this genus are very effective as botanical insecticides against several arthropods, including mosquitoes. Piper tuberculatum and Piper aduncum extracts were highly effective against larvae and engorged female Rhipicephalus microplus ticks [13, 44]. The essential oil of $P$. nigrum exhibited insecticidal activity against the mosquito species Ae. aegypti, Anopheles stephensi and Culex quinquefasciatus [28]. A study performed in the Brazilian Amazon comparing the methanol leaf and root extracts from several local plants, at the concentration of $500 \mu \mathrm{g} / \mathrm{mL}$ (500 ppm), reported $P$. aduncum to have very good activity against Ae aegypti, showing 100\% mortality after $24 \mathrm{~h}$, similarly to our results, because of the phytochemical compound dillapiole [32]. Previous studies indicate a relevant potential for dillapiole to be used as a synergist compound in combination with pyrethroid-based insecticides to control Ae. aegypti [28].

O. campechianum was already used as an insecticide against white fly Aleurodicus cocois (Curtis, 1846) (Hemiptera, Aleyrodidae) [22]. Researchers carried out a study testing essential oils from $O$. americanum and $O$. gratissimum against larvae of Ae. aegypti and obtained $\mathrm{LC}_{50}$ values of $67 \mathrm{ppm}$ and $60 \mathrm{ppm}$ respectively, values very close to the $69.29 \mathrm{ppm}$ of O. campechianum found here [10]. The literature indicates that eugenol, the main compound of $O$. campechianum essential oil studied in this research, exhibits larvicidal activity against Ae. aegypti at the concentration of $44.5 \mathrm{ppm}$. Therefore, the larvicidal activity of $O$. campechianum essential oil against this mosquito species could be highly associated with the presence of eugenol [6].

Concerning the essential oil of $O$. quixos, it has rarely been reported for its possible use against mosquito larvae as it is used mainly as a disinfectant, local anaesthetic, and anti-diarrheic infusion [5]. However, the results reported here about $O$. quixos
$($ LD99 $=181.89 \mathrm{ppm})$ are consistent with findings on Ocotea cymbarum, showing that its strongest toxic effect was $100 \%$ mortality in Ae. aegypti third age larvae at concentrations $\geq 30 \mathrm{ppm}$ [23]. Previous studies on the monoterpene 1,8-cineole, which is the main constituent of $O$. quixos oil in this experiment, showed larvicidal activity toward the larvae of several mosquitos including Ae. aegypti and Ae. albopictus. The hydrophobicity of 1,8-cineole is probably the main factor responsible for toxicity towards larvae, because cuticle penetration is facilitated [12].

The larvicidal activity of all three biological compounds was evaluated at $24 \mathrm{~h}$ after treatment and it was found to be high for all of the three oils.

However, it should be noted that costly and lengthy authorisation processes and the low environmental persistence of essential oils (and thus their effects) strongly limit the availability on the market of commercial insecticidal and repellent products. In addition, botanical larvicides (Bls) based on EOs may exhibit different efficacy depending on the postapplication temperature of the environment, and this effect seems to be related to the non-uniform behaviour of their major constituents [30]. In order to provide clear and practical recommendations for application of such BIs, it is fundamental to understand the relationship between post-application temperature and the insecticidal efficacy of EOs. Therefore, further studies to investigate this aspect are needed.

An additional aspect that markedly limits the development of such products for real use is the undeniable lack of field studies validating the efficacy of herbal extracts as mosquito larvicides. Nevertheless, some promising results regarding field experiments have been reported in a recent review article concerning the application of herbal extracts as mosquito larvicides [31]. Herein, at least 14 research studies are mentioned as showing preliminary and encouraging results on the treatment of external water storage reservoirs or sewage water bodies as typical breeding sites for Ae. aegypti, Ae. albopictus, $C x$. quinquefasciatus and An. stephensi.

Clearly, several biological insecticides based on Spinosad or Bacillus thuringiensis var. israelensis (B.t.i.), currently used for mosquito control, show greater efficacy than the oils tested in this study and in others. According to Bond et al. and Romi et al. [8, 37], the larvicidal activity of Spinosad ranged between 0.01 and $0.02 \mathrm{ppm}\left(\mathrm{LC}_{50}\right.$ and $\mathrm{LC}_{99}$ respectively at $24 \mathrm{~h}$ after treatment), and similar larvicidal activity was reported for B.t.i [20]. 
For completeness of comparison, we report the susceptibility of Ae. aegypti to the organothiophosphate insecticide Fenthion, used as a positive control in this study, as a lethal dose of $0.05 \mathrm{ppm}$, corresponding to the $\mathrm{LC}_{99}$ for this species [47].

Finally, our results show clear larvicidal activity against $A e$. aegypti for all three essences, with $P$. aduncum essential oil displaying a greater efficacy when compared to $O$. campechianum and $O$. quixos oils.

Further studies are of course needed to understand the effectiveness of the various components present in each extracted oil and the mechanisms of action that are at the basis of their larvicidal activity against $A e$. aegypti.

In conclusion, the rapid and effective larvicidal activity of the three oils led us to consider results to be promising, considering that these plants are commonly widespread as wild species all over the Ecuadorian Amazon Region. In addition, they could also be easily cultivated on human-controlled systems, both locally and in other tropical countries. Reproduction of $O$. campechianum plants usually occurs through spontaneous seed dissemination, while $O$. quixos and $P$. aduncum reproduce through vegetative processes. Lastly, essential oils from these plant species can be prepared using simple technology.

\section{Conflict of interest}

The authors declare that there are no conflicts of interest.

Acknowledgements. This research was supported by a grant from the Universidad Estatal Amazónica, Ecuador and a grant from the University of Ferrara, Italy. The present article was produced within the framework of the MAE - DNB - CM - 2015 - 0027 agreement in force between the Ministry of the Environment of Ecuador and the Universidad Estatal Amazónica. Finally, we are grateful to the anonymous reviewers for their valuable comments.

\section{References}

1. Abbott WS. 1925. A method of computing the effectiveness of an insecticide. Journal of Economic Entomology, 18(2), 265-267.

2. Adams RP. 2007. Identification of Essential Oil Components by Gas Chromatography/Mass Spectrometry, 4th ed. IL, USA: A. P. C. C. Stream, Ed.

3. Atanasov AG, Waltenberger B, Pferschy-Wenzig EM, Linder T, Wawrosch C, Uhrin P, Temml V, Wang L, Schwaiger S, Heiss EH, Rollinger JM, Schuster D, Breuss JM, Bochkov V, Mihovilovic MD, Kopp B, Dirsch VM, Stuppner H. 2015. Discovery and resupply of pharmacologically active plantderived natural products: A review. Biotechnology Advances, 33(8), 1582-1614.

4. Bakkali F, Averbeck S, Averbeck D, Idaomar M. 2008. Biological effects of essential oils - a review. Food and Chemical Toxicology, 46(2), 446-475.

5. Ballabeni V, Tognolini M, Bertoni S, Bruni R, Guerrini A, Rueda GM, Barocelli E. 2007. Antiplatelet and antithrombotic activities of essential oil from wild Ocotea quixos (Lam.) Kosterm. (Lauraceae) calices from Amazonian Ecuador. Pharmacological Research, 55(1), 23-30.

6. Barbosa JDF, Silva VB, Alves PB, Gumina G, Santos RLC, Sousa DP, Cavalcanti SCH. 2012. Structure-activity relationships of eugenol derivatives against Aedes aegypti (Diptera: Culicidae) larvae. Pest Management Science, 68(11), 1478-1483.

7. Bhalla Y, Gupta VK, Jaitak V. 2013. Anticancer activity of essential oils: a review. Journal of the Science of Food and Agriculture, 93(15), 3643-3653.

8. Bond JG, Marina CF, Williams T. 2004. The naturally derived insecticide spinosad is highly toxic to Aedes and Anopheles mosquito larvae. Medical and Veterinary Entomology, 18(1), $50-56$.

9. Bruni R, Medici A, Andreotti E, Fantin C, Muzzoli M, Dehesa M, Romagnoli C, Sacchetti G. 2004. Chemical composition and biological activities of Ishpingo essential oil, a traditional Ecuadorian spice from Ocotea quixos (Lam.) Kosterm. (Lauraceae) flower calices. Food Chemistry, 85(3), 415-442.

10. Cavalcanti ES, Morais SM, Lima MA, Santana EW. 2004. Larvicidal activity of essential oils from Brazilian plants against Aedes aegypti L. Memórias do Instituto Oswaldo Cruz, 99(5), 541-544.

11. Chareonviriyaphap T, Bangs MJ, Suwonkerd W, Kongmee M, Corbel V, Ngoen-Klan R. 2013. Review of insecticide resistance and behavioral avoidance of vectors of human diseases in Thailand. Parasites and Vectors, 6, 280.

12. Costa A, Naspi C, Lucia A. 2017. Repellent and larvicidal activity of the essential oil from Eucalyptus nitens against Aedes aegypti and Aedes albopictus (Diptera: Culicidae). Journal of Medical Entomology, 54(3), 670-676.

13. Da Silva Lima A, Do Nascimento Sousa Filho JG, Garcia Pereira S, Skelding Pinheiro Guillon GM, Da Silva Santos L, Costa Júnior LM. 2014. Acaricide activity of different extracts from Piper tuberculatum fruits against Rhipicephalus microplus. Parasitology Research, 113(1), 107-112.

14. Darsie RF, Ward RA. 2005. Identification and geographical distribution of the mosquitoes of North America, North of Mexico. Gainesville, FL: University of Florida Press, 1-313.

15. Deschamps C, Raskin I, Simon J. 2008. Regulation of essential oil in Basil (Ocimum basilicum L.) in response to elicitation. International Journal of Plant Sciences, 169(8), 981-986.

16. Finney DJ. 1952. Probit analysis, 2nd edn. Journal of the Institute of Actuaries, 78(3), 388-390.

17. Finney DJ. 1971. Probit analysis, 3rd edn. Cambridge, United Kingdom: Cambridge University Press, Edition.

18. Guerrini A, Sacchetti G, Rossi D, Paganetto G, Muzzoli M, Andreotti E, Tognolini M, Maldonado ME, Bruni R. 2009. Bioactivities of Piper aduncum L. and Piper obliquum Ruiz \& Pavon (Piperaceae) essential oils from Eastern Ecuador. Environmental Toxicology and Pharmacology, 27(1), 39-48.

19. Guerrini A, Rossi D, Grandini A, Scalvenzi L, Rivera PFN, Andreotti E, Tacchini M, Spagnoletti A, Poppi I, Maietti S, Sacchetti G. 2014. Biological and chemo-diverse characterization of Amazonian (Ecuador) Citrus petitgrains. Journal of Applied Botany and Food Quality, 87, 108-116.

20. Klowden MJ, Held GA, Bulla LA. 1983. Toxicity of Bacillus thuringiensis subsp. israelensis to adult Aedes aegypti mosquitoes. Applied and Environmental Microbiology, 46(2), 312-315.

21. Mittermeier RA, Goettsch CM. 1997. Megadiversity: Earth's biologically wealthiest nations. San Pedro Garza García, México: CEMEX Conservation Book Series.

22. Mota MSCS, Silva RS, Silva GA, Picanco MC. 2017. Potential of allelochemicals from basil (Ocimum micranthum Willd.) to control whitefly (Aleurodicus cocois (Curtis 1846)) in cashew nut crop (Anacardium occidentale L.). Allelopathy Journal, 40(2), 197-208.

23. Narciso JO, Soares RO, Dos Santos Reis, Mallet J, Guimarães AÉ, de Oliveira Chaves MC, Barbosa-Filho JM, Maleck M. 
2014. Burchellin: study of bioactivity against Aedes aegypti. Parasites and Vectors, 7, 172.

24. Newman DJ, Cragg GM. 2007. Natural products as sources of new drugs over the last 25 years. Journal of Natural Products, 70(3), 461-477.

25. Noriega P, Dacarro C. 2008. Aceite foliar de Ocotea quixos (Lam.) Kosterm.: actividad antimicrobiana y antifúngica. La Granja, Revista de Cencias de la Vida, 7(1), 3-8.

26. Obeng-Ofori D, Reichmuth C. 1997. Bioactivity of eugenol, a major component of essential oil of Ocimum suave (Wild.) against four species of stored-product coleoptera. International Journal of Pest Management, 43(1), 89-94.

27. Oliveira Gomes E, Massayoshi Nunomura S, Marinotti O, Tadei WP. 2016. Synergistic potential of dillapiole combined with pyrethroids against mosquitoes. Vector Biology Journal, 1(3), 8-11.

28. Park IK, Lee SG, Shin SC, Park JD, Ahn YJ. 2002. Larvicidal activity of isobutylamides identified in Piper nigrum fruits against three mosquito species. Journal of Agricultural and Food Chemistry, 50(7), 1866-1870.

29. Pavela R. 2016. History, presence and perspective of using plant extracts as commercial botanical insecticides and farm products for protection against insects: a review. Plant Protection Science, 52(4), 229-241.

30. Pavela R, Sedlák P. 2018. Post-application temperature as a factor influencing the insecticidal activity of essential oil from Thymus vulgaris. Industrial Crops \& Products, 113, 43-49.

31. Pavela R, Maggi F, Iannarelli R, Benelli G. 2019. Plant extracts for developing mosquito larvicides: From laboratory to the field, with insights on the modes of action. Acta Tropica, 193(2019), 236-271.

32. Pohlit AM, Quinard ELJ, Nunomura SM, Tadei WP, Hidalgo A de F, Pinto AC da S, Santos AC da S, Morais EVM, Saraiva SKR, Ming RCG, Alecrim LC, Ferraz AM, Pedroso AB, Diniz AC da S, Finney EV, Gomes EK, Dias E de O, Souza HB, Oliveira KS, Don LCP, Queiroz LC, Henrique MMA, Santos MC, Lacerda Júnior M, Pinto O da S, Silva P de S, Gomes S, Graça YR. 2004. Screening of plants found in the State of Amazonas, Brazil for activity against Aedes aegypti larvae. Acta Amazonica, 34(1), 97-105.

33. Radice M, Silva J, Correa C, Moya A, Escobar JA, Pérez Martínez A. 2016. Ocotea quixos essential oil: a systematic review about the ethno-medicinal uses, phytochemistry and biological activity. Conference: MOL2NET 2017, International Conference on Multidisciplinary Sciences, 3rd edition, 15 February-30 November 2017; Sciforum Electronic Conference Series Volume: Vol. 3, 2017.

34. Radice M, Pietrantoni A, Guerrini A, Tacchini M, Sacchetti G, Chiurato M, Venturi G, Fortuna C. 2018. Inhibitory effect of Ocotea quixos (Lam.) Kosterm. and Piper aduncum L. essential oils from Ecuador on West Nile virus infection. Plant Biosystems - An International Journal Dealing with all Aspects of Plant Biology. DOI: 10.1080/11263504.2018.1478902.

35. Rathy M, Sajith U, Harilal C. 2015. Plant diversity for mosquito control: a preliminary study. International Journal of Mosquito Research, 2(1), 29-33.

36. Rolli E, Marieschi M, Maietti S, Sacchetti G, Bruni R. 2014. Comparative phytotoxicity of 25 essential oils on pre- and postemergence development of Solanum lycopersicum L.: a multivariate approach. Industrial Crops and Products, 60, 280-290.
37. Romi R, Proietti M, Di Luca M, Cristofaro M. 2006. Laboratory evaluation of the bioinsecticide Spinosad for mosquito control. Journal of the American Mosquito Control Association, 22(1), 93-96.

38. Sacchetti G, Medici A, Maietti S, Radice M, Muzzoli M, Manfredini S, Braccioli E, Bruni R. 2004. Composition and functional properties of the essential oil of Amazonian Basil, Ocimum micranthum Willd., Labiatae in comparison with commercial essential oils. Journal of Agricultural and Food Chemistry, 52(11), 3486-3491.

39. Sacchetti G, Guerrini A, Noriega P, Bianchi A, Bruni R. 2006. Essential oil of wild Ocotea quixos (Lam.) Kosterm. (Lauraceae) leaves from Amazonian Ecuador. Flavour and Fragrance Journal, 21(4), 674-676.

40. Salleh WMNHW, Ahmad F. 2017. Phytochemistry and biological activities of the genus Ocotea (Lauraceae): a review on recent research results (2000-2016). Journal of Applied Pharmaceutical Science, 7(05), 204-218.

41. Scalvenzi L, Yaguache B, Cabrera P, Guerrini A. 2016. Actividad antifúngica in vitro de aceites esenciales de Ocotea quixos Lam (Kosterm.) y Piper aduncum L. Bioagro, 28(1), 39-46.

42. Scalvenzi L, Grandini A, Spagnoletti A, Tacchini M, Neill D, Ballesteros JL, Sacchetti G, Guerrini A. 2017. Myrcia splendens (Sw.) DC. (syn. M. fallax (Rich.) DC.) (Myrtaceae) essential oil from Amazonian Ecuador: A chemical characterization and bioactivity profile. Molecules, 22(7), 1-12.

43. Sierra R, Campos F, Chamberlin J. 2002. Assessing biodiversity conservation priorities: ecosystem risk and representativeness in continental Ecuador. Landscape and Urban Planning, 59(2), 95-110.

44. Silva WC, Martins JR, de Souza HE, Heinzen H, Cesio MV, Mato M, Albrecht F, de Azevedo JL, de Barros NM. 2009. Toxicity of Piper aduncum L. (Piperales: Piperaceae) from the Amazon forest for the cattle tick Rhipicephalus (Boophilus) microplus (Acari: Ixodidae). Veterinary Parasitology, 164(2-4), 267-274.

45. Tognolini M, Barocelli E, Ballabeni V, Bruni R, Bianchi A, Chiavarini M, Impicciatore M. 2006. Comparative screening of plant essential oils: Phenylpropanoid moiety as basic core for antiplatelet activity. Life Sciences, 78(13), 1419-1432.

46. Tunç I, Şahinkaya Ş. 1998. Sensitivity of two greenhouse pests to vapours of essential oils. Entomologia Experimentalis et Applicata, 86(2), 183-187.

47. W.H.O. 1981. Instructions for determining the susceptibility or resistance of mosquito larvae to insecticides. Geneva: World Health Organization.

48. W.H.O. 2006. Pesticides and their application for the control of vectors and pests of public health importance. Geneva: World Health Organization.

49. W.H.O. 2016a. Media center, fact sheets, yellow fever. Geneva: World Health Organization.

50. W.H.O. 2016b. Statement on the third meeting of the International Health Regulations (2005) (IHR(2005)). Emergency Committee on Zika virus and observed increase in neurological disorders and neonatal malformations. Retrieved November 30, 2017, from http://www.who.int/mediacentre/news/statements/ 2016/zika-third-ec/en/.

Cite this article as: Scalvenzi L, Radice M, Toma L, Severini F, Boccolini D, Bella A, Guerrini A, Tacchini M, Sacchetti G, Chiurato M, Romi R \& Di Luca M. 2019. Larvicidal activity of Ocimum campechianum, Ocotea quixos and Piper aduncum essential oils against Aedes aegypti. Parasite 26, 23. 
Reviews, articles and short notes may be submitted. Fields include, but are not limited to: general, medical and veterinary parasitology; morphology, including ultrastructure; parasite systematics, including entomology, acarology, helminthology and protistology, and molecular analyses; molecular biology and biochemistry; immunology of parasitic diseases; host-parasite relationships; ecology and life history of parasites; epidemiology; therapeutics; new diagnostic tools.

All papers in Parasite are published in English. Manuscripts should have a broad interest and must not have been published or submitted elsewhere. No limit is imposed on the length of manuscripts.

Parasite (open-access) continues Parasite (print and online editions, 1994-2012) and Annales de Parasitologie Humaine et Comparée (1923-1993) and is the official journal of the Société Française de Parasitologie. 